\title{
From Preservice to Practice: Expectations of/in the Secondary ELA Classroom
}

\author{
Tiffany Karalis Noel ${ }^{1, *} \&$ Melanie Shoffner ${ }^{2}$ \\ ${ }^{1}$ University at Buffalo, Buffalo NY 14228, USA \\ ${ }^{2}$ James Madison University, Harrisonburg VA 22807, USA \\ *Correspondence: University at Buffalo, Buffalo NY 14228, USA. Tel: 1-716-645-2455. E-mail: \\ tbkarali@buffalo.edu
}

Received: October 29, 2019

Accepted: November 27, 2019 Online Published: December 18, 2019

doi:10.5430/wje.v9n6p35

URL: https://doi.org/10.5430/wje.v9n6p35

\begin{abstract}
The paper explores how preservice ELA teachers' expectations of teaching compare to the reality of their experiences during the first year of teaching. The authors consider common concerns of beginning ELA teachers and their implications for teacher self-efficacy. The paper is informed by narrative research, which provides practical and specific insights into the lived experiences of participants. The first data set consists of reflective writings on a self-identified topic connected to ELA teaching and/or learning throughout the semester. Two, one-hour individual interviews conducted during the first year of teaching form the second data set. The paper provides empirical insights about how preservice experiences inform ELA teachers' expectations of first-year teaching and their development of self-efficacy. Their two major concerns - classroom management and building rapport - identified their fears and insecurities about managing disruptive students and establishing connections with students. These struggles offer a connection between expectations, experiences and self-efficacy. Likewise, they point to the need for teacher education to address preservice teachers' self-efficacy as a way to support their successful entry into the classroom. The paper includes implications for the development of increased opportunities to study and experience critical concerns of the profession. Such learning experiences offer preservice teachers meaningful opportunities to engage with experiential learning, applied practice and critical reflection before their first year in the field. The paper fulfills an identified need to study how differences between expectation and reality can be difficult for beginning ELA teachers to reconcile, a disconnect that lends itself to considerations of teachers' self-efficacy.
\end{abstract}

Keywords: teacher candidates, early-career teachers, teacher self-efficacy, field experience

\section{Introduction}

Teaching is a decidedly difficult act, requiring English Language Arts (ELA) teachers to respond to constantly changing subject matter, standards and students that are shaped by complex societal, cultural, political and socioeconomic factors (Brauer \& Clark, 2008; Hawthorne et al., 2012; McCann, Johannessen \& Ricca, 2005). Teaching is especially difficult for those entering the profession:

Their knowledge and skills are necessarily limited by their recent entry into the classroom and their developing understanding of teaching and learning, yet they are given the same roles and responsibilities as veteran teachers. While developing as classroom teachers, beginning teachers must also negotiate issues of identity, belief, responsibility, and expectation. (Shoffner, 2011, p. 417)

Teacher educators work to address these diverse issues through focused coursework, challenging expectations and authentic field experiences to better prepare preservice ELA teachers for what they will face as beginning teachers (Shoffner, 2011; McDonald, Bowman, \& Brayko, 2013; Whitney, Olan, \& Fredricksen, 2013). Still, the differences between expectation and reality can be difficult for beginning ELA teachers to reconcile (Shoffner, 2010a, 2010b; McCann, Johannessen, \& Rica, 2005), a disconnect that lends itself to considerations of teachers' self-efficacy.

Self-efficacy is an individual's belief in his or her ability to produce specific performance attainments and exert control over one's own motivation, behavior, and social environment (Bandura, 1986). For example, a teacher's self-efficacy — or level of confidence about their ability to teach a wide range of students and maintain proficiency in 
all skills required to be a successful educator - may greatly depend on their past experiences or current school culture (Aloe et al., 2013). Therefore, for beginning teachers, expectations of and experiences during the first year may shape their self-efficacy and, in turn, their classroom interactions and practices.

This article explores teacher self-efficacy through preservice ELA teachers' expectations of teaching and their lived experiences of teaching in the first year. The authors first provide a working definition of self-efficacy before considering the common concerns of beginning ELA teachers. Next, they outline a qualitative study that examined three beginning secondary ELA teachers' expectations of teaching during teacher preparation and experiences in their first year of teaching. Using the major concerns identified by the teachers during preparation and the first year classroom management and building rapport - the authors then examine the ELA teachers' expectations of and experiences with teaching before considering the potential implications of these concerns for teacher self-efficacy and, by extension, teacher education.

\section{Literature Review}

\subsection{Understanding Self-Efficacy}

Grounded in social cognitive theory, Bandura's (1986) concept of self-efficacy is defined as one's belief in their ability to perform in certain ways in order to complete specific tasks and meet determined objectives (Bandura, 1977; Pajares, 1996; Schunk, 1995). While self-efficacy influences and is influenced by one's performance on a task, it is also influenced by the feedback itself and how one interprets that feedback.

Teacher self-efficacy is defined as the "judgment of [one's] own capabilities to bring about desired outcomes of student engagement and learning, even among those students who may be difficult or unmotivated" (Tschannen-Moran \& Hoy, 2001, p. 783). Colleagues and administrators who do not acknowledge or support teachers working in negative conditions - e.g., when schools lack supplies or offer a chaotic environment—are leading factors in stripping teachers of their self-efficacy (Johnson, Berg, \& Donaldson, 2005). However, as Tschannen-Moran and Hoy (2007) found in their study of 255 novice and experienced teachers, pedagogical preparation and interpersonal support from colleagues and administrators "were found to be much more salient in the self-efficacy beliefs of novice teachers" (p. 944), suggesting that teachers' beliefs about their capacity to teach effectively are connected to their education prior to classroom teaching.

Teacher education may contribute to a teacher's sense of self-efficacy (Byrne, 2017; Carr, 2013; Johnson, Berg, \& Donaldson, 2005). For example, if teachers enter the classroom with a thorough understanding of their content but lack the necessary pedagogical understanding to connect that knowledge to student learning, their self-efficacy may be affected and, by extension, their willingness to stay in the field. Perhaps unsurprisingly, teacher turnover is "highest among beginners" (Ingersoll, Merrill, \& May et al., 2014, p. 5) who, without the proper preparation, may become overwhelmed by the daily stressors and unexpected hurdles they face (Guarino, Santibanez, \& Daley, 2006; Fry, 2007; Stein \& Stein, 2016) and, by extension, develop a decreased sense of self-efficacy. Teachers who possess an increased or high sense of self-efficacy, however, are more likely to overcome the inevitable challenges they face throughout their early-career teaching experiences (Bandura, 1977; 1986; Ozder, 2011). While some studies assert that teacher education programs do not prepare preservice teachers to effectively manage the major stressors of initial teaching years (Rieg, Paquette, \& Chen, 2007), providing teachers with a thorough introduction to the job's expectations, along with positive support and mentorship from colleagues and administrators, can help beginning teachers navigate the challenges of first-year teaching and bolster their willingness to remain in the profession (Darling-Hammond, 2003).

\subsection{Beginning as English teachers}

Beginning teachers must navigate a range of issues while adjusting to the administrative, academic, contextual and personal demands of teaching (e.g., Shoffner, 2010b; Flores \& Day, 2006; Kyriacou \& Kunc, 2007). As Swan, Wolf \& Cano (2011) found in their study of teacher self-efficacy from student teaching through the third year of teaching, teachers reported the lowest levels of self-efficacy at the conclusion of their first year. Research indicates a decrease in teacher self-efficacy during the first year of teaching, potentially attributed to the loss of direct mentorship during the student teaching experience (Woolfolk Hoy \& Burke Spero, 2005), a disconnect between knowledge gleaned through teacher preparation, and the "reality shock" that occurs when first-year teachers face challenges and demands they do not feel prepared to handle (Veenman, 1984; Tygret, 2018). Beginning teachers face a range of challenges in their first years of teaching as they learn to navigate relationships, workload/time management, subject matter knowledge, evaluation/grading, autonomy/control, physical/personal appearance (McCann, Johannesen, \& Ricca, 2005), adjustment to the profession, acceptance of students and management of emotion (Shoffner, 2011). However 
frustrations manifest for beginning teachers, however, "the mismatch between the teacher's expectations for the experience of teaching and the realization of the actual experience" (McCann, Johannesen, \& Ricca, 2005, p. 21; italics in original) serves as the common denominator.

The difference between expectation and experience plays an important role in how teachers perceive their entry into the classroom (Shoffner, 2010a; Flores \& Day, 2006; Lortie, 2002). Beginning teachers' "confrontations with the realities and responsibilities of being a classroom teacher...[put] their beliefs and ideas about teaching to the test, challenges some of them, and confirms others" (Kelchtermann \& Ballet, 2002, p. 105). Despite preservice teachers' valuing of practical experience in the classroom - through which they often dismiss their university coursework or theoretical understandings (Whitney, Olan \& Fredriksen, 2013) - these experiences cannot entirely prepare them for the complexity of classroom teaching.

The difficulties beginning teachers encounter when they enter the classroom are likely to influence their self-efficacy, a connection that holds implications for teacher education since studies have found that comprehensive teacher education preparation is positively correlated with teacher self-efficacy (Ingersoll et al., 2014, p. 3; Johnson et al., 2005; McLaurin et al., 2009; Whitney et al., 2002). Teachers who are not adequately prepared are likely to be overwhelmed by the daily stressors and unexpected hurdles they face in their first years (Borman \& Dowling, 2008; Guarino, Santibanez, \& Daley, 2006; Perda, 2013). Structuring teacher education programs "with an eye to the sources of self-efficacy, such as abundant opportunities for the observation of teaching strategies...and the provision of specific, useful, and encouraging feedback on early teaching-experiences" supports preservice teachers' cultivation of high self-efficacy beliefs and supports their entering first year "with a robust sense of their capabilities" (Tschannen-Moran \& MacFarlane, 2010, p. 220).

\section{Methodology}

This study is informed by narrative research (Creswell, 2012), which provides practical and specific insights into the lived experiences of participants. The study draws on the lived experiences of three secondary ELA teachers: Hannah, Tori and Rocky (pseudonyms). In 2009, they were English majors in a secondary teacher education program at a large Midwestern Research 1 institution. In 2010, they were in their first year of teaching, having remained in the same Midwestern state as the university. Hannah, a white woman, taught multi-grade basic skills and $8^{\text {th }}$ and $9^{\text {th }}$ grade ELA at a rural high school. Tori, also a white woman, taught $8^{\text {th }}$ grade at a suburban middle school. Rocky, a white man, taught $10^{\text {th }}, 11^{\text {th }}$ and $12^{\text {th }}$ grade ELA at an urban high school.

The first data set consists of reflective writings. As preservice teachers, Hannah, Tori and Rocky took Shoffner's secondary ELA methods course in Fall 2009. One assignment required preservice teachers to submit reflections on a self-identified topic connected to ELA teaching and/or learning throughout the semester; these reflections often referenced a concurrent field experience. Seven reflections were collected from each student, for a total of 21 reflections.

Individual interviews form the second data set. Shoffner conducted two in-person interviews with each teacher in their first year of teaching, one in Fall 2010 and one in Spring 2011, for a total of six interviews. Each interview lasted approximately one hour and was transcribed for analysis.

Content analysis (Patton, 2002) was used to analyze the reflective writings and interview transcripts. Themes were identified and grouped by locating frequently used words and phrases in the data, then coded using general terms, such as students; as analysis continued, themes were narrowed to more specific terms, such as working with students. Themes were compared across the two data sets, resulting in the final major themes of classroom management and building rapport.

\section{Findings}

\subsection{Expectations of Teaching ELA}

As preservice teachers, Hannah, Tori and Rocky held many expectations about ELA teaching and learning. Analysis of their reflective writings revealed two major concerns connected to those expectations: classroom management and building rapport.

Classroom management. Classroom management was the first major concern expressed by the preservice teachers during their university preparation. In her reflections, Hannah noted her frustrations when working with "difficult" students: 
I attempted to clarify the prompt and was bombarded by interruptions, like, "Is this going to be taken for a grade? Why are you giving us more homework?" amid several other disrespectful glares and eye-rolls. After multiple interruptions, I raised my voice over the din of questions and complaints.

She questioned how to handle students making inappropriate comments and when to involve the principal in classroom issues. She also struggled with her own impatience at apparently unmotivated students.

While Hannah was initially eager to work with misbehaving students, she admitted that it was challenging to redirect negative behavior. Her difficulty dealing with students' actions sometimes resulted in personal behavior she regretted: "In retrospect, I should not have taken my frustrations out on him...I need to learn to better do this." At the end of her field experience, Hannah admitted that she had viewed content knowledge as the main part of the job. After her time in the classroom, she recognized that classroom management was equal, if not more, important challenge: "I have witnessed the best and worst of high school students, and the miracle of the matter is that I haven't even run away screaming yet."

Tori also noted concerns with classroom management during her field experience, although hers related to large class sizes and computer-based classroom limitations. Her experience in a classroom utilizing computer-based instruction meant that students worked independently and at their own pace. Not surprisingly, she found it difficult to interact with students in meaningful ways: "It is very difficult for me to set up a classroom community because all of the students are working individually on different subjects." Tori was unsure how to implement classroom management in such a situation; she was uncomfortable "telling students not to do certain things... it is impossible to have your eye on everything the students are doing."

By the end of semester, Tori expressed more irritation with student behavior than the difficulty of working in the computer-focused environment: "One of the students rolled her eyes at the thought of being pulled away from her computer to learn [with me]. This annoyed me." She recognized the importance of managing such behavior, admitting that "I generally don't like bad attitudes [but] this is something I will deal with on a constant basis from students."

Rocky's reflections frequently focused on positive experiences in the classroom and his attempts to "be flexible" in his management style. His challenges with classroom management came with his uncertainty at implementing improvisational comedy techniques in his future classroom:

A concern I have is will students get out of control...Improvisation is fun, but I hope students can use improvisation as a tool for learning, and not get out of control playing the games. If I do not implement improvisation properly, I could have chaos.

Building rapport. Building rapport with students was the second major concern for the preservice teachers. Hannan expressed her frustration with students that were disruptive, inattentive and unwilling to take her seriously. She pointed to an incident when her cooperating teacher told students she was a junior at the local university; after that, she felt "they refused to pay attention to someone so close to their own age." Hannah's disconnect with her students was revealed again when she dealt with a student plagiarism:

When I asked [him] why he plagiarized, his response was that I had only observed them twice when I decided that they were capable of writing a college level essay and that I shouldn't have assumed they were able to write that way.

Despite negative interactions, however, Hannah concluded her reflections on a positive note, feeling she had built a "fairly solid rapport" with her students because she spent time talking with them before class and made an effort to make them feel "like their opinions mattered."

Tori's concerns with building rapport focused on building connections with diverse students in the classroom. As she explained, "I am nervous because I don't really know how to help students who don't speak English and also because I don't really know how to communicate with them." As the semester progressed, she began to see connections between understanding students' contexts and building rapport with them: "I [worried] students would be troubled and unmotivated...I have really gained a better understanding of their personal situations."

Rocky's reflections revealed positive interactions with students; he felt he was able to build rapport with students in his field experience early on. His concern with building rapport once again turned to his future classroom. As he explained, "I asked myself, how would I keep these students motivated? How would I challenge these students? Professionally, I have to find ways to help them reach their full potential." 


\subsection{Experiences of Teaching ELA}

In their first year of teaching, Hannah, Tori and Rocky expressed concern with the same major issues identified during their university preparation: classroom management and building rapport.

Classroom management. After four months in the classroom, Hannah was generally positive about her classroom management skills. She noted her increased confidence in dealing with issues: "I feel like my classroom management has improved tremendously." By the end of her first year, however, Hannah's views were more complex. She mused that she had "a very complicated relationship with my students" and described having to leave her classroom one day, overwhelmed by the inability to manage them: "There have been occasions where I really couldn't get control of my classroom...I have actually left the classroom and had to take a couple of minutes to breathe."

At the beginning of the year, Tori's issues with classroom management were related to large class size: "I have 50 kids per class period... we had to make lessons up because nobody told us what to do." By the end of the year, her classroom management had changed in specific ways: "In the beginning, I was a little more laid-back, but I got a lot stricter and I don't have a problem with yelling at a kid...I have gotten really angry." She found herself arguing with misbehaving students - "I get mad because they start arguing with me and I keep it going until I catch myself" although she knew that was not the way she wanted to manage her classroom.

Despite a difficult year, Tori was generally positive: "It's been an experience, that's for sure...my own personal feelings are getting better." She described how employing stricter management techniques throughout the year had allowed her to manage her classroom more effectively, despite the fact that she initially anticipated being a laid-back teacher: "I think that I am way stricter than I thought I was going to be... I just don't put up with a lot of things anymore." However, when asked about the most difficult part of her first year as a teacher, Tori identified classroom management: "Taking care of discipline issues was a learning experience. That's my least favorite part of teaching."

Rocky's challenges with classroom management at the beginning of the year frequently related to his sense of humor; he found that students sometimes struggled to read his intent because of his use of humor. As one student told him, "I don't know when you're being serious or goofy." Rocky was understanding of his students' misbehaviors, as he remembered what it was like to be bored and unruly in class. Although he knew he needed to improve his classroom management skills, he was reluctant to be the "mean" teacher:

You don't want to be the guy who sends a person down [to the office] every day, even though that would probably get you more control... That's one of the things I struggle with, because you don't know if you're going to lose a kid that way.

By the end of the year, however, Rocky had adopted a much stricter approach to classroom management. His frustration with students' continued misbehavior was evident: "I'm trying to teach and they're yelling." Rocky knew he had "gotten worse" at classroom management but was also willing to improve going forward: "I know there's going to be a lot of failures, but it's about [learning from] those failures."

Building rapport. At the beginning of the year, Hannah described several instances of effective rapport-building with students while maintaining her professional boundaries: "[I] have to reinforce that boundary and say, 'No, we're not friends. I am your teacher, you are my student.' There's a certain conduct that has to be avoided." Despite Hannah's concern about the conflation of friendship and teacher relationship, she found that she had developed more rapport with her students as the year progressed: "I have become ridiculously attached to these kids...I used to be a teacher that refused physical contact with kids. Now, my kids hug me... and I'm okay with it.

Tori was noticeably concerned about building rapport with her students from the beginning of the year: "One day [students] hate you, one day they like you, and then they hate you again! I've never been so unsure of myself in my entire life." Despite her uncertainties, Tori's feelings towards her students were positive: "I feel really emotionally attached to them...some of them really like me and that feels good. For every kid that I think hates me, the kid that likes me just makes it better." At the end of the year, however, Tori's confidence had decreased: "I'm giving [the students] everything that I can and [they're] not giving me anything back, so I'm just going to stop wasting my time... some of these kids I've just really given up on." She noted that she wanted to support student learning, rather than worry about her feelings, but it was difficult to "find a happy medium between caring about students liking me and learning from me."

Rocky's positive attitude about building rapport with students persisted into his first year: "I go out of my way to connect with my students and I feel like they have a good relationship with me." However, he also recognized that his efforts to creating rapport could lead to behavior issues: "I feel like I made a good connection with the kids, almost — maybe — too good of a connection with the kids." Explaining what "too good" meant, Rocky said, "They see 
me as the lighter side rather than a more rigorous teacher." He described how students would not take his attempts at classroom management seriously because of his laid-back personality and use of humor. Like Hannah and Tori, Rocky expressed concern about building rapport with students while managing behavior their behavior, fearing that "if you have a looser classroom and give students more freedom, they will take advantage of it." At the end of the year, Rocky's attitude had not shifted significantly. Although he felt fairly successful in connecting with his students "I'm happy here...[the students] love me as much as I love them"- his knew he wanted to develop classroom management strategies while maintaining his rapport-building skills.

\section{Discussion}

\subsection{Beginning Teachers and Self-Efficacy}

Hannah, Tori, and Rocky's preservice experiences provide insight into their expectations of first-year teaching and their development of self-efficacy. Their two major concerns - classroom management and building rapport identified their fears and insecurities about managing disruptive students and establishing connections with students. Hannah and Tori expected to be unsuccessful in managing their classrooms and building rapport with students during their first year of teaching, suggesting low initial self-efficacy. Conversely, Rocky's positive experiences and first-year expectations suggest high initial self-efficacy. He was confident that he would connect with students, specifically by using humor in the classroom.

Although Hannah experienced some success with classroom management following her initial low self-efficacy, she found that managing large groups of disruptive students was something she was unprepared to handle, which seemed to negatively impact her self-efficacy. She was pleasantly surprised, however, at her ability to establish rapport with students in the first year, indicating an increase in her self-efficacy from initial expectations.

Feeling that she could neither control students' behavior nor establish rapport at the beginning of the year, Tori felt hopeless when working with students, indicating low self-efficacy. After taking steps to enforce stricter classroom management policies, Tori's self-efficacy was improved at the end of the year but tempered by her belief that classroom management was a "waste of [her] energy" that "beat [her] down." By becoming a "stricter" teacher, Tori believed relationships with her students were negatively affected; she felt that she could not maintain positive relationships with difficult students, especially those she had "given up on." By the end of her first year, Tori's experiences with classroom management and building rapport had further decreased the self-efficacy initially expressed as a preservice teacher.

Rocky's positive expectations of his first year suggested high self-efficacy. This declined throughout his first year, however, as he realized the difficulty of using humor in the classroom, gaining students' respect and maintaining their engagement. Although Rocky expected to easily establish rapport with students, indicating high self-efficacy, his lived experiences suggested that "too much" rapport with students negatively impacted his self-efficacy. Rocky believed that, because students felt comfortable with him as a result of his laid-back nature and humor-based pedagogy, they did not take him seriously and dismissed his authority, indicating a decrease in self-efficacy from his initial expectations.

Evidenced by numerous studies (e.g., Everston, 1985; Sanford \& Everston, 1985; Lewis et al. 2005, Morris-Rothschild \& Brassard, 2006), quality teaching depends on effective classroom management strategies, requiring teachers to "believe in themselves, their instruction, and their management of students" (Dibapile, 2012, p.80). Throughout Hannah, Tori and Rocky's first year, they dealt with different issues of classroom management: students' interruptions, reactions to homework assignments, inappropriate comments in written work, plagiarism, ineffective attempts at establishing boundaries. All three teachers' self-efficacy appeared to decrease when navigating the middle ground between "being a pushover" so that students took advantage and "being too strict" so that students shut down, a response supported by studies that identify classroom management as an ongoing struggle for novice teachers (Carr, 2013; Dunn, 2009; Hicks, 2012; Byrne, 2017). Their positive response whenever a classroom management-related strategy proved effective is supported by Schunk (1991), who asserted that individuals work far more strenuously when they judge themselves confidently and fit to succeed — even in the face of challenging circumstances - rather than when they deem themselves incapable of performing a task.

Findings from previous studies reveal the importance of establishing rapport with students to increase teacher self-efficacy beliefs and improve classroom connectedness (e.g., Tschannen-Moran \& Barr, 2004; Huber et al., 2016; Wang et al., 2017; Lavado, 2018). While Hannah, Tori and Rocky's self-efficacy beliefs decreased whenever they felt they were "doing so much for the students" but "not receiving anything in return", their self-efficacy beliefs 
appeared to increase whenever they experienced breakthroughs in the classroom, such as increased participation and positive feedback. Their self-efficacy shifts are supported by Frisby and Martin (2010), whose findings revealed instructor-student rapport as the only factor that consistently predicted classroom connectedness and enhanced student participation. Previous studies also confirm the positive correlation between classroom connectedness and teacher self-efficacy (e.g., Chong \& Kong, 2012; Moyer, 2015; Usher \& Pajares, 2008; Wyatt, 2013; Lavado, 2018).

\section{Implications for Teacher Education}

Beginning teachers' experiences are riddled with positive and negative events which both align and conflict with their preservice expectations. Classroom management and student relationships are issues clearly addressed in teacher education but beginning teachers frequently struggle in these areas (e.g., Shoffner, 2010a, 2010b, 2011; McCann, Johannessen \& Ricca, 2005). These struggles offer a connection between expectations, experiences and self-efficacy. Likewise, they point to the need for teacher education to address preservice teachers' self-efficacy is a way to support their successful entry into the classroom.

For example, beginning teachers should be encouraged to reflect on the lived experiences of their first year, in contrast to their preservice expectations, and share these with teacher educators. In turn, teacher educators can better understand, support and respond to those teachers' concerns by enhancing coursework and field-based opportunities to specifically address concerns - like the concerns of classroom management and building rapport noted here - and support future self-efficacy.

In addition, preservice teachers should have increased opportunities to study and experience critical concerns of the profession. For instance, teacher educators can incorporate teachers' real-life teaching experiences into university coursework (e.g., Shoffner, 2019), create opportunities for preservice teachers to collaborate with practicing teachers (e.g., Levin \& Rock, 2003), structure fieldwork experiences to address specific issues (e.g., McDonald, Bowman \& Brayko, 2013), and/or implement professional development activities throughout teacher preparation (e.g., Isch \& Rodesiler, 2019). Such learning experiences offer preservice teachers meaningful opportunities to engage with experiential learning, applied practice and critical reflection before their first year in the field. By better preparing preservice teachers for the realities of the classroom, teacher educators can better support the development of their self-efficacy as beginning teachers.

\section{References}

Aloe, A. M., Amo, L. C., \& Shanahan, M. E. (2013). Classroom management self-efficacy and burnout: A multivariate meta-analysis, 26, 101-126. https://doi.org/10.1007/s10648-013-9244-0

Bandura, A. (1977). Self-efficacy: Toward a unifying theory of behavioral change. Psychological Review, 84, 191-215. https://doi.org/10.1037/0033-295X.84.2.191

Bandura, A. (1986). Social foundations of thought and action: A social cognitive theory. Englewood Cliffs, NJ: Prentice-Hall.

Borman, G. D., \& Dowling, N. M. (2008). Teacher attrition and retention: A meta-analytic and narrative review of the research. Review of Educational Research, 78, 367-409. https://doi.org/10.3102/0034654308321455

Brauer, L., \& Clark, C. T. (2008). The trouble is English: Reframing English studies in secondary schools. English Education, 40(4), 293-313.

Byrne, K. C. (2017). Teacher self-efficacy in classroom management amongst novice middle school teachers. (Ed.D. Dissertation)

Carr, D. (2013). The effects of teacher preparation programs on novice teachers regarding classroom management, academic preparation, time management and self-efficacy. (Doctoral dissertation).

Chong, W. H., \& Kong, C. A. (2012). Teacher collaborative learning and teacher self-efficacy: The case of lesson study. The Journal of Experimental Education, 80(3), 263-283. https://doi.org/10.1080/00220973.2011.596854

Clandinin, D. J., \& Connelly, F. M. (1990). Stories of experience and narrative inquiry. Educational Researcher, 19(5), 2-14. https://doi.org/10.3102/0013189X019005002

Creswell, J. W. (2012). Educational research: Planning conducting and evaluating quantitative and qualitative research (4th ed.). Boston, MA: Pearson.

Darling-Hammond, L. (2003). Access to quality teaching: An analysis of inequality in California's public schools. 
Santa Clara Law Review, 43, 101-239.

Dibapile, W. (2012). A review of literature on teacher efficacy and classroom management. Educational Psychology \& Counseling Publications and Other works, 9(2), 79-92. https://doi.org/10.19030/tlc.v9i2.6902

Dunn, S. H. (2009). Preservice teacher preparation for managing behavior problems. An interpretive qualitative analysis of the classroom management course. (Doctoral dissertation)

Evertson, C. M. (1985). Training teachers in classroom management: an experimental study in secondary school classrooms. Journal of Educational Research, 79(1), 51-58. https://doi.org/10.1080/00220671.1985.10885648

Flores, M. A., \& Day, C. (2006). Contexts which shape and reshape new teachers' identities: A multi-perspective study. Teaching and Teacher Education, 22, 219-232. https://doi.org/10.1016/j.tate.2005.09.002

Frisby, B., \& Martin, M. (2010). Instructor-student and student-student rapport in the classroom. Communication Education, 59(2), 146-164. https://doi.org/10.1080/03634520903564362

Fry, S. W. (2007). First-year teachers and induction support: Ups, downs, and in-betweens. The Qualitative Report, 12(2), 216-237.

Guarino, C., Santibanez, L., \& Daley, G. (2006). Teacher recruitment and retention: A review of the recent empirical literature. Review of Educational Research, 76(1), 173-208. https://doi.org/10.3102/00346543076002173

Hawthorne, S., Goodwyn, A., George, M., Reid, L., \& Shoffner, M. (2012). The state of English education: Considering possibilities in troubled times. English Education, 44(3), 288-311.

Hicks, S. D. (2012). Self-efficacy and classroom management: A correlation study regarding the factors that influence classroom management. (Doctoral dissertation)

Huber, M. J., Fruth, J. D., Avila-John, A., \& Rodriquez, E. (2016). Teacher self-efficacy and student outcomes: A transactional approach to prevention. Journal of Education and Human Development, 5(1), 46-54. https://doi.org/10.15640/jehd.v5n1a5

Ingersoll, R., Merrill, L., \& May, H. (2014). What Are the Effects of Teacher Education Preparation on Beginning Teacher Attrition? Consortium for Policy Research in Education (Vol. RR-82). Philadelphia, PA: Consortium for Policy Research in Education, University of Pennsylvania.

Isch, A., \& Rodesiler, L. (2019). Developing as professionals, learning as preservice teachers. English Journal, 108(3), 102-104.

Johnson, S. M., Berg, J. H., \& Donaldson, M. L. (2005). Who stays in teaching and why: A review of the literature on teacher retention. Cambridge, MA: Project on the Next Generation of Teachers.

Kelchtermans, G., \& Ballet, K. (2002). The micropolitics of teacher induction: A narrative-biographical study on

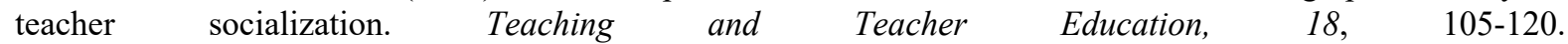
https://doi.org/10.1016/S0742-051X(01)00053-1

Kyriacou, C., \& Kunc, R. (2007). Beginning teachers' expectations of teaching. Teaching and Teacher Education, 23(8), 1246-1257. https://doi.org/10.1016/j.tate.2006.06.002

Lavado, K. (2018). Influences on the sources of teacher self-efficacy in a Lutheran school. Ed.D. Dissertations, 115.

Lewis, R., Romi, S., Qui, X., \& Katz, Y. J. (2005) Teacherse classroom discipline and student misbehavior in Australia, China and Israel. Teaching and Teacher Education, 21, 729-741. https://doi.org/10.1016/j.tate.2005.05.008

Levin, B. B., \& Rock, T. C. (2003). The effects of collaborative action research on preservice and experienced teacher partners in professional development schools. Journal of Teacher Education, 54(2), 135-149. https://doi.org/10.1177/0022487102250287

Lortie, D. C. (2002). Schoolteacher: A sociological study. Chicago: University of Chicago Press.

McCann, T. M., Johannessen, L. R., \& Ricca, B. P. (2005). Supporting beginning English teachers: Research and implications for teacher induction. Urbana, IL: National Council of Teachers of English.

McDonald, M. A., Bowman, M., \& Brayko, K. (2013). Learning to see students: Opportunities to develop relational practices of teaching through community-based placements in teacher education. Teachers College Record, 115(4), 1-35.

McLaurin, S. E., Smith, W., \& Smillie, A. (2009). Teacher retention: Problems and solutions. Retrieved from 
http://files.eric.ed.gov/fulltext/ED507446.pdf

Morris-Rothschild, B. K., \& Brassard, M. R. (2006). Teachers' conflict management styles: The role of attachment styles and classroom management efficacy. Journal of School Psychology, 44, 105-121. https://doi.org/10.1016/j.jsp.2006.01.004

Moyer, M. E. (2015). Professional development, teacher efficacy, and student achievement (Doctoral dissertation).

Ozder, H. (2011). Self-efficacy beliefs of novice teachers and their performance in the classroom. Australian Journal of Teacher Education, 36(5), 1-15. https://doi.org/10.14221/ajte.2011v36n5.1

Pajares, F. (1996). Self-efficacy beliefs in academic settings. Review of Educational Research, 66(4), 543-578. https://doi.org/10.3102/00346543066004543

Patton, M. Q. (2002). Qualitative research \& evaluation methods (3rd ed.). Thousand Oaks, CA: Sage.

Perda, D. (2013). Transitions into and out of teaching: A longitudinal analysis of early career teacher turnover (Unpublished doctoral dissertation). University of Pennsylvania, Philadelphia.

Reynolds, A., Ross, S. M., \& Rakow, J. H. (2002). Teacher retention, teaching effectiveness, and professional preparation: A comparison of teacher professional development school and nonprofessional development school graduates. Teaching and Teacher Education, 18, 289-303. https://doi.org/10.1016/S0742-051X(01)00070-1

Rieg, S. A., Paquette, K. R., \& Chen, Y. (2007). Coping with stress: An investigation of novice teachers' stressors in the elementary classroom. Education, 128(2), 201-226.

Sanford, J. P., \& Evertson, C. A. (1985). Classroom management in low ses junior high: Three case studies. Journal of Teacher Education, 32(1), 34-38. https://doi.org/10.1177/002248718103200108

Schunk, D. H. (1991). Self-efficacy and academic motivation. Educational Psychologist, 26, 207-231. https://doi.org/10.1207/s15326985ep2603\&4_2

Schunk, D. H. (1995). Self-efficacy, motivation, and performance. Journal of Applied Sport Psychology, 7(2), 112-137. https://doi.org/10.1080/10413209508406961

Shoffner, M., de Oliveira, L. C., \& Angus, R. (2010a). Multiliteracies in the secondary English classroom: Becoming literate in the $21^{\text {st }}$ century. English Teaching: Practice and Critique, 9(3), 75-89.

Shoffner, M., \& Wachter Morris, C. A. (2010b). Preparing preservice English teachers and school counselor interns for future collaboration. Teaching Education, 21(2), 185-197. https://doi.org/10.1080/10476210903183894

Shoffner, M. (2011). Considering the first year: Reflection as a means to address beginning teachers' concerns. Teaching and Teacher Education, 25(6), 783-789. https://doi.org/10.1016/j.tate.2008.11.012

Shoffner, M. (2019). Being uncomfortable is important: The potential of study abroad for preservice English teachers' professional development. Pedagogies: An International Journal, 14(3), 93-108. https://doi.org/10.1080/1554480X.2019.1597721

Stein, L., \& Stein, A. (2016). Rethinking America's teacher education programs. The Clearing House: A Journal of Educational Strategies, Issues and Ideas, 89(6), 191-196. https://doi.org/10.1080/00098655.2016.1206427

Swan, B. G., Wolf, K. J., \& Cano, J. (2011). Changes in teacher self-efficacy from the student teaching experience through the third year of teaching. Journal of Agricultural Education, 52(2), 128-139. https://doi.org/10.5032/jae.2011.02128

Tschannen-Moran, M., \& Hoy, A. W. (2001). Teacher efficacy: Capturing an elusive construct. Teaching and Teacher Education, 17(7), 783-805. https://doi.org/10.1016/S0742-051X(01)00036-1

Tschannen-Moran, M., \& Barr, M. (2004). Fostering student learning: The relationship of collective teacher efficacy and student achievement. Leadership and Policy in Schools, 3(3), 189-209. https://doi.org/10.1080/15700760490503706

Tschannen-Moran, M., \& Hoy, A. W. (2007). The differential antecedents of self-efficacy beliefs of novice and experienced teachers. Teaching and Teacher Education, 23(6), 944-956. https://doi.org/10.1016/j.tate.2006.05.003

Tschannen-Moran, M., \& MacFarlane, B. (2010). I know I can!: Teacher self-efficacy in the English Language Arts classroom. In D. Lapp \& D. Fisher. The handbook of research on teaching the English language arts (3rd ed.), (pp. 218-223). Philadelphia, PA: Erlbaum/Taylor Francis. 
Tygret, J. A. (2018). The preparation and education of first-year teachers: A case study. The Qualitative Report, 23(3), 710-729.

Usher, E. L., \& Pajares, F. (2008). Sources of self-efficacy in school: Critical review of the literature and future directions. Review of Educational Research, 78(4), 751-796. https://doi.org/10.3102/0034654308321456

Veenman, S. (1984). Perceived problems of beginning teachers. Review of Educational Research, 54, 143-178. https://doi.org/10.3102/00346543054002143

Wang, L. Y., Tan, L. S., Li, J. Y., Tan, I., \& Lim, X. F. (2017). A qualitative inquiry on sources of teacher efficacy in teaching low-achieving students. The Journal of Educational Research, 110(2), 140-150. https://doi.org/10.1080/00220671.2015.1052953

Whitney, L., Golez, F., Nagel, G., Nieto, C., \& Nieto, C. (2002). Listening to voices of practicing teachers examine the effectiveness of a teacher education program. Action in Teacher Education, 23(3), 69-76. https://doi.org/10.1080/01626620.2002.10463090

Whitney, A. E., Olan, E. L., \& Fredricksen, J. E. (2013). Experience over all: Preservice teachers and the prizing of the "practical". English Education, 45(2), 184-201.

Woolfolk, H. A., \& Burke, S. R. (2005) Changes in teacher efficacy during the early years of teaching: A comparison of four measures. Teaching and Teacher Education, 21, 343-356. https://doi.org/10.1016/j.tate.2005.01.007

Wyatt, M. (2013). Overcoming low self-efficacy beliefs in teaching English to young learners. International Journal of Qualitative Studies in Education, 26(2), 238-255. https://doi.org/10.1080/09518398.2011.605082 